series is somewhat high. While the method of alphabetization adopted is strictly correct, it may prove in practice to be less convenient than the 'catchword' method used in the "World List", as a research worker frequently depends upon short abbreviations, and is unacquainted with unimportant particles on which the alphabetical order depends. In addition, the adoption of a strict alphabetical sequence tends to separate periodicals dealing with the same subject, which a 'catchword' method tends to bring together. The volume is well printed in a clear type, and although the titles of the periodicals are all in languages foreign to the place of publication, the work is remarkably free from printer's errors. This catalogue affords evidence of Japanese enterprise in the field of bibliography, and it is obvious that very considerable care has been taken in its compilation. It should be of much value to scientific workers resident in Japan.

\section{The Industrial Health Research Board}

THE eighteenth annual report of the Industrial Health Research Board up to June 1938 (H.M. Stationery Office. 1s. net) contains a summary of the results of twenty years work, and describes the work of the current year. During its twenty years of activity, an attempt has been made to discover new ways and means of improving working conditions in factories and workshops, and the results of shortening the hours of labour, of splitting up shifts and of introducing rest pauses have been studied, and the influence of environmental conditions and methods of work upon the output and the health of the workers has been investigated. During the present year, the Board has investigated the relation between illumination and industrial efficiency, problems of noise and deafness, dust and ill-health, toxic solvents, work at high temperatures and ventilation. Vocational psychology applied to vocational selection and guidance in industry, vocational tests for skilled and unskilled occupations and tests of accident proneness are other subjects to which considerable attention is now being directed.

\section{Principal Earthquakes during 1937}

IN 1937 there were no really great earthquakes, but damage was done by eight shocks, and several others were felt by human beings in various parts of the world. The eight which did damage were Guelma (Algeria), February 10 ; Rabaul, $4^{\circ} 10^{\prime} \mathrm{S}$. , $152^{\circ} 10^{\prime}$ E. (New Britain), May 28; Maltrata (Mexico), July 26 ; Tsao-Tchéou (China), August 1; Manila (Philippines), August 20; Samarang (Java), September 27; Mexico City, December 23; and Oxapampa (Peru), December 29. These and others are discussed by Prof. J. P. Rothé, of Strasbourg, in Revue pour l'Étude des Calamités, 1, No. 2, 1938, under six regional headings: continent of Europe, Mediterranean region, continent of Asia, Asiatic islands and circum-Pacific coastlines, the American continent and the African continent with Madagascar. It is noteworthy that no disastrous earthquake was felt in Europe, and the only one reported from Britain was near Birmingham.

\section{The Philosophical Society}

Tнe Philosophical Society of England celebrated its silver jubilee on December 7 with a luncheon at St. Ermin's Restaurant, London, and a lecture by the Rev. I. Hartill, a vice-president of the Society, on "John Milton". Various speakers emphasized the useful purpose of the Society, its steady development and its practical achievements. Messages were sent by the American Ambassador, Lord Gorell and Prof. A. E. Heath, who were unable to attend. This Society was founded in 1913 by a group of persons interested in the moral sciences, with the view of promoting the study of philosophy among the general public. The Society publishes the Philosopher, holds meetings and organizes lectures from time to time. Also it encourages the formation of local centres and study circles, and the introduction of matters of philosophical interest in schools and other educational institutions. Its vice-presidents include many distinguished philosophers, and a number of eminent scholars from abroad are among its honorary fellows.

\section{Sir George Beilby Memorial Awards}

THE administrators of the Beilby Memorial Fund - the presidents, treasurers and secretaries of the Institute of Chemistry, the Society of Chemical Industry and the Institute of Metals respectivelyhave awarded one hundred guineas each to Dr. F. P. Bowden and Dr. Brynmor Jones. Dr. Bowden was educated at the Hutchins School, Hobart, and at the University of Tasmania. He went to Cambridge in 1927, entered Gonville and Caius College and continued electrochemical work in the laboratory of physical chemistry with Prof. E. K. Rideal and Prof. T. M. Lowry. In 1931 he was elected to a research fellowship at Caius College and was appointed University demonstrator in chemistry. In 1937 he was appointed to the Humphrey Owen Jones lectureship in physical chemistry. His electrochemical work has been mainly on over-potential and the mechanism of electro-deposition. His other work on the physical properties of surfaces has an im. portant bearing on the problems of friction, lubrication and wear. Dr. B. Jones studied metallurgy during 1919-22 at University College, Cardiff, under Prof. A. E. Read. From 1927 until 1929 he was attached to the Metallurgical Branch of the Research Department of Woolwich Arsenal, and afterwards was appointed lecturer in metallurgy at University College, Cardiff. Dr. Jones has devised many methods in metallurgical analyses. His outstanding published work has been on the subject of the nitrogen-hardening and on the heat-treatment of steels, which has been appearing in the Transactions of the Iron and Steel Institute.

\section{Physical Society's Annual Meeting}

THE twenty-ninth annual exhibition of scientific instruments and apparatus, arranged by the Physical Society, will be held at the Imperial College of Science and Technology, Imperial Institute Road, South Kensington, S.W.7, on January 3-5. The leading manufacturers of scientific instruments will be exhibit- 
ing their latest products in the Trade Section. The Research and Educational Section will contain contributions from research laboratories, and experiments of educational interest. In addition, the work submitted for the Craftsmanship and Draughtsmanship Competition by apprentices and learners will be on view. Discourses will be delivered at 7.45 on January 3 by Dr. J. D. Cockeroft, on "The Cyclotron and its Applications", and on January 4 by Mr. C. S. Wright, on "Geophysical Research in Polar Regions". Admission to the exhibition is by ticket only, obtainable from scientific societies or direct from the Exhibition Secretary, 1 Lowther Gardens, Exhibition Road, S.W.7.

\section{British Association: Dundee Meeting}

THE annual meeting of the British Association will be held next year in Dundee from August 30 until September 6 under the presidency of Sir Albert Seward. The following sectional presidents have been appointed: Section A (Mathematical and Physical Sciences), Mr. R. S. Whipple; Section B (Chemistry), Prof. E. K. Rideal ; Section C (Geology), Prof. H. H. Read; Section D (Zoology), Prof. J. Ritchie; Section E (Geography), Mr. A. Stevens; Section F (Economics), Prof. H. O. Meredith; Section G (Engineering), Mr. H. E. Wimperis; Section $H$ (Anthropology), Prof. W. E. Le Gros Clark ; Section I (Physiology), Prof. D. Burns ; Section J (Psychology), Mr. R. J. Bartlett; Section K (Botany), Prof. D. Thoday; Section L (Education), Dr. A. P. M. Fleming; Section M (Agriculture), Sir Thomas Middleton.

\section{Colonial Service Appointments}

THE following appointments and promotions in the Colonial Service have recently been made : J. E. R. Roe, veterinary officer, Uganda; T. Bell (Government Stock Farm and Agricultural Station, Acre, Palestine), agricultural superintendent, British Guiana; W. A. Gordon (assistant conservator of forests, Gold Coast), assistant conservator of forests, Cyprus ; G. W. St. Clair-Thompson (assistant conservator of forests, Gold Coast), assistant conservator of forests, Uganda; J. H. Gibbons (chief inspector of mines, Northern Rhodesia), senior inspector of mines, Tanganyika Territory; K. E. Lee (assistant inspector of mines, Uganda), inspector of mines, Federated Malay States; I. Humphrey (supervisor of physical training, Sierra Leone), meteorological assistant, Nigeria.

\section{Announcements}

SIR JoHN ForsDyke, director and principal librarian of the British Museum, and Mr. John L. Kirk, honorary director of the Castle Museum, York, have recently been elected honorary members of the Yorkshire Philosophical Society, York.

AT a reception on December 6 at the Belgian Embassy, Baron de Cartier de Marchienne, the Ambassador, presented a number of bronze medals awarded by King Leopold of the Belgians to various
British scientific workers. The medals, bearing on one side the head of King Leopold and on the other the name of the recipient, and the occasion of the award, were a token of appreciation for the help given by the various specialists in classifying the natural history collections which the King of the Belgians made in 1928-29 during his voyage to the East. The recipients, most of whom were present at the Embassy, were: Sir Guy Marshall, Dr. K. Jordan, Dr. Isabella Gordon, Dr. S. Maulik, Dr. W. H. Leigh-Sharpe, Miss G. Ricardo, Mr. C. L. Collenette, Mrs. L. M. I. Macfadyn, Mr. W. H. T. Tams, Mr. H. E. Andrewes, Miss I. Meyrick (for her late father, Mr. E. Meyrick), Prof. H. Gordon Jackson, Dr. H. Hanitsch, Mr. C. J. Arrow, Dr. Evelyn Cheesman, Dr. Marie V. Lebour, Dr. Schwarz, Mr. L. B. Prout, Mr. A. J. T. Janse and Lieut.-Colonel F. C. Fraser.

Dr. Irving LANGMUIR will deliver an address before the Physical Society on December 20 at 5.15. The subject of Dr. Langmuir's address will be "The Structure of Proteins".

AN industrial fellowship has been established in the Mellon Institute, Pittsburgh, by the American Air Filter Company, Inc., of Louisville, $\mathrm{Ky}$. This fellowship will aid investigations on materials of value in the construction of filters for air-conditioning systems. Dr. Frank F. Rupert, who has been appointed to the fellowship, has been a member of the Mellon Institute since 1913. Since 1935 he has been associated with the fellowship on air hygiene in the Institute.

UNDER the terms of administration of the Clough Memorial Research Fund of the Edinburgh Geological Society a sum of approximately $£ 30$ is available annually for the purpose of encouraging geological research in Scotland and the north of England. The north of England is defined as comprising the counties of Northumberland, Cumberland, Durham, Westmorland and Yorkshire. Applications for grants are invited for the period April 1, 1939-March 31, 1940, and should reach the Secretary, Clough Research Fund Committee, Edinburgh Geological Society, Synod Hall, Castle Terrace, Edinburgh, not later than February 1, 1939.

ThE fourth Oxford Farming Conference will be held at Oxford on January 3-5, under the auspices of the School of Rural Economy, the Agricultural Economics Research Institute and the Institute for Research in Agricultural Engineering of the University. The general theme of the Conference will be "The Business Organization of the Farm". Further information can be obtained from the Conference Secretary, 10 Parks Road, Oxford.

The Cambridge University Press will publish early in the New Year "A Short History of the Steam Engine", by Mr. H. W. Dickinson, formerly of the Science Museum, South Kensington. The author, it is stated, discusses not only the inventions, but also the inventors. 